\title{
Near normalisation of blood glucose improves the potentiating effect of GLP-1 on glucose-induced insulin secretion in patients with type 2 diabetes
}

\author{
P. V. Højberg • M. Zander • T. Vilsbøll • F. K. Knop • \\ T. Krarup • A. Vølund • J. J. Holst • S. Madsbad
}

Received: 8 July 2007 / Accepted: 30 November 2007 / Published online: 22 February 2008

(C) Springer-Verlag 2008

\begin{abstract}
Aims/hypothesis The ability of glucagon-like peptide-1 (GLP-1) to enhance beta cell responsiveness to i.v. glucose is impaired in patients with type 2 diabetes mellitus compared with healthy individuals. We investigated whether 4 weeks of near normalisation of blood glucose (BG) improves the potentiation of glucose-stimulated insulin secretion by GLP-1.

Methods Nine obese patients with type 2 diabetes and inadequate glycaemic control $\left(\mathrm{HbA}_{1 \mathrm{c}} 8.0 \pm 0.4 \%\right)$ were investigated before and after 4 weeks of near normalisation of BG using insulin treatment (mean diurnal blood glucose $6.4 \pm 0.3 \mathrm{mmol} / 1, \mathrm{HbA}_{1 \mathrm{c}} 6.6 \pm 0.3 \%$ ). Nine matched healthy participants were also studied. Beta cell function was investigated before and after insulin treatment using stepwise glucose infusions and infusion of saline or GLP$1\left(1.0 \mathrm{pmol} \mathrm{kg} \mathrm{min}^{-1}\right)$, resulting in supraphysiological total GLP-1 concentrations of approximately $200 \mathrm{pmol} / 1$. The responsiveness to glucose or glucose+GLP-1 was
\end{abstract}

P. V. Højberg $(\bowtie) \cdot$ M. Zander $\cdot$ S. Madsbad

Department of Endocrinology, Hvidovre Hospital,

Kettegaards Allé 30,

2650 Hvidovre, Denmark

e-mail: pmvc@dadlnet.dk

P. V. Højberg · T. Vilsbøll • F. K. Knop · T. Krarup

Department of Internal Medicine F, Gentofte Hospital,

Hellerup, Denmark

\section{A. Vølund}

Department of Biostatistics, Novo Nordisk,

Bagsværd, Denmark

\section{J. J. Holst}

Department of Medical Physiology, The Panum Institute,

University of Copenhagen,

Copenhagen, Denmark expressed as the slope of the linear regression line relating insulin secretion rate (ISR) and plasma glucose concentration ( $\mathrm{pmol} \mathrm{kg}{ }^{-1} \mathrm{~min}^{-1}[\mathrm{mmol} / \mathrm{l}]^{-1}$ ).

Results In the diabetic participants, the slopes during glucose+saline infusion did not differ before and after insulin treatment $(0.33 \pm 0.07$ and $0.39 \pm 0.04$, respectively; $p=\mathrm{NS}$ ). In contrast, near normalisation of blood glucose improved beta cell sensitivity to glucose during glucose + GLP-1 infusion ( $1.27 \pm 0.2$ before vs $1.73 \pm 0.31$ after; $p<$ $0.01)$. In the healthy participants, the slopes during the glucose + saline and glucose+GLP-1 infusions were $1.01 \pm$ 0.14 and $4.79 \pm 0.53$, respectively.

Conclusions/interpretation A supraphysiological dose of GLP-1 enhances beta cell responses to glucose in patients with type 2 diabetes, and 4 weeks of near normalisation of blood glucose further improves this effect.

\section{ClinicalTrials.gov ID no.: NCT00612625}

Keywords Alpha cell function - Beta cell responsiveness . GLP-1 - Glucotoxicity - Intensive insulin treatment .

Type 2 diabetes

$\begin{array}{ll}\text { Abbreviations } \\ \text { GIP } & \text { glucose-dependent insulinotropic polypeptide } \\ \text { GLP-1 } & \text { glucagon-like peptide 1 } \\ \text { ISR } & \text { insulin secretion rate }\end{array}$

\section{Introduction}

Impaired pancreatic beta cell function is a characteristic defect of type 2 diabetes mellitus, and can be explained by decreases in both beta cell number and beta cell function 
$[1,2]$. The first-phase insulin response to i.v. glucose is already absent in the early stages of the disease, whereas the beta cell response to non-glucose secretagogues is preserved, although reduced compared with healthy individuals [2]. In people with normal glucose tolerance, glucosedependent insulinotropic polypeptide (GIP) and glucagonlike peptide-1 (GLP-1) are responsible for the incretin effect, which describes the augmentation of insulin secretion that results from oral compared with i.v. glucose stimulation of secretion [3], and together they account for up to $70 \%$ of the insulin response following oral glucose loads [4]. Several investigators have shown that the incretin effect is attenuated in patients with type 2 diabetes, primarily because of a reduced insulinotropic effect of GIP, while the effect of GLP-1 is relatively more preserved [5-8]. GLP-1 potentiates beta cell responsiveness to glucose in a dose-dependent manner, and this sensitivity to glucose can be increased to normal levels by the infusion of a slightly supraphysiological dose of GLP-1 [9, 10]. However, the dose-response relationship between GLP-1 and its potentiation of the beta cell response to glucose is impaired in patients with type 2 diabetes [9].

In individuals with type 2 diabetes, there is considerable evidence that prolonged exposure of the beta cells to high glucose levels induces functional defects in insulin secretion in response to both glucose and non-glucose secretagogues [11]. Glucotoxicity is known to be partly reversible, since restoration of normoglycaemia with insulin in patients with type 2 diabetes has been shown to improve beta cell function [12-17]. We therefore hypothesised that improved glycaemic control might also enhance the potentiating effect of GLP-1. In the present study we assessed whether 4 weeks of intensive insulin treatment, designed to near normalise blood glucose in patients with type 2 diabetes, improves the ability of GLP-1 to enhance glucose-induced insulin secretion. Furthermore, since plasma glucagon concentrations are elevated in patients with type 2 diabetes and do not decrease appropriately after food intake [18], and given that GLP-1 is known to suppress glucagon secretion $[19,20]$, a secondary objective of the study was to investigate whether near normalisation of blood glucose alters the effects of glucose and GLP-1 on glucagon secretion.

\section{Methods}

\section{Participants}

The characteristics of the participants at baseline are presented in Table 1 . Nine patients with type 2 diabetes (six men) aged $53 \pm 8$ years (mean $\pm \mathrm{SD}$ ), and nine healthy volunteers (six men) aged $55 \pm 7$ years $($ mean $\pm \mathrm{SD})$ with a fasting plasma glucose level of $5.0 \pm 0.3 \mathrm{mmol} / 1$ were
Table 1 Characteristics of the participants at baseline

\begin{tabular}{|c|c|c|}
\hline & $\begin{array}{l}\text { Patients with } \\
\text { type } 2 \text { diabetes }\end{array}$ & $\begin{array}{l}\text { Healthy control } \\
\text { subjects }\end{array}$ \\
\hline Age (years) & $53 \pm 8$ & $55 \pm 7$ \\
\hline Duration of diabetes (years) & $5 \pm 4$ & \\
\hline BMI $\left(\mathrm{kg} / \mathrm{m}^{2}\right)$ & $31 \pm 4$ & $31 \pm 5$ \\
\hline $\mathrm{HbA}_{1 \mathrm{c}}(\%)$ & $8.0 \pm 0.4$ & $5.4 \pm 0.1$ \\
\hline Fructosamine $(\mu \mathrm{mol} / \mathrm{l})$ & $316 \pm 20$ & $220 \pm 8$ \\
\hline
\end{tabular}

Data are means \pm SD

studied. The BMIs of the two groups were $31 \pm 4$ and $31 \pm$ $5 \mathrm{~kg} / \mathrm{m}^{2}$ (mean $\pm \mathrm{SD}$ ), respectively. None of the healthy volunteers had a family history of diabetes, and all had normal oral glucose tolerance as assessed by $75 \mathrm{~g}$ OGTTs. Neither patients nor healthy controls had islet cell autoantibodies or glutamate decarboxylase- 65 autoantibodies.

Prior to entering the study, the diabetic individuals had $\mathrm{HbA}_{1 \mathrm{c}}$ levels of $8.0 \pm 0.4 \%$ (mean $\left.\pm \mathrm{SD}\right)$ and fructosamine levels of $316 \pm 20 \mu \mathrm{mol} / 1 \quad$ (mean $\pm \mathrm{SD}$; normal values $<285 \mu \mathrm{mol} / \mathrm{l}$ ). The mean duration of disease from diagnosis was $5 \pm 4$ years (mean $\pm \mathrm{SD}$ ), and the patients did not suffer from any overt diabetic complications or any other somatic medical illnesses. Two of the nine patients were treated with diet only, six were treated with metformin and one patient was treated with metformin and sulfonylurea. The patients did not take any other drugs known to affect carbohydrate metabolism. Hypoglycaemic agents were discontinued at least 3 weeks before each experiment. All studies were carried out at the Department of Endocrinology at the Copenhagen University Hospital at Hvidovre (Copenhagen, Denmark), and all participants agreed to participate after receiving oral and written information. The ethics committee in Copenhagen Municipality approved the protocol and the study was performed in accordance with the Declaration of Helsinki.

The patients were investigated as described below, before and after 4 weeks of insulin treatment. Glycaemic control before the start of insulin treatment was evaluated from the blood glucose seven point profile, determined for days, which involved the measurement of blood glucose before and $1.5 \mathrm{~h}$ after each main meal and at 22:00 hours. Additionally, $\mathrm{HbA}_{1 \mathrm{c}}$ and plasma fructosamine were measured.

Insulin treatment

To optimise glycaemic control, patients were treated with multiple insulin injections. Insulin therapy, including administration of a fast-acting insulin analogue before each meal, as well as basal insulin coverage by intermediate-acting (NPH) insulin administered twice daily, was based on selfmonitored blood glucose using a One Touch Ultra meter (Life Scan, Johnson and Johnson, Milpitas, CA, USA). 
During the first week, participants measured blood glucose seven times daily and had daily telephone contact with the principal investigator to regulate insulin therapy, with the objective of achieving a targeted fasting (prebreakfast) blood glucose level of $<5 \mathrm{mmol} / 1$ (without incurring unacceptable risk of hypoglycaemia) and a targeted postprandial blood glucose level of $<8 \mathrm{mmol} / \mathrm{l}$. During the following 3 weeks of treatment, participants measured blood glucose seven times daily on 2 weekdays, and four times daily on the other 5 weekdays. Insulin adjustment was made before each insulin injection in accordance with an algorithm based on the measured blood glucose concentrations, to achieve the targeted blood glucose levels.

\section{Experimental protocol}

The patients were investigated on separate days using graded glucose infusions together with an infusion of GLP-1 (1 pmol kg-1 $\left.\mathrm{min}^{-1}\right)$ or saline, both before and after 4 weeks of insulin treatment, giving a total of four experimental days. Less than one week was allowed to pass between saline and GLP-1 experiments, which were performed in random order. All patients completed all four experiments, whereas the healthy participants were only investigated once with GLP-1 and once with saline. The evening before each investigation, the patients were treated with Mixtard (30/70; Novo Nordisk, Bagsvaerd, Denmark) at bedtime to obtain a fasting blood glucose level between 6 and $10 \mathrm{mmol} / \mathrm{l}$. None of participants displayed a blood glucose level below $5.0 \mathrm{mmol} / \mathrm{l}$ the evening and night before experiments according to blood glucose measurements made at 22:00, 03:00 and 07:00 hours. The participants attended the ward at 08:00 hours, after fasting (including abstinence from smoking) from 22:00 hours the evening before. Studies were performed with the participants in a recumbent position, and i.v. catheters were placed in each forearm, one for blood sampling and one for infusion. The hand with the sampling catheter was heated. At the beginning of the experiment the patients received a continuous i.v. infusion of fast-acting insulin (Actrapid; NovoNordisk) at a rate of $0.1 \mathrm{IU} \mathrm{kg}^{-1} \mathrm{~h}^{-1}$. Once plasma glucose reached $6 \mathrm{mmol} / \mathrm{l}$, the infusion was stopped (time $-60 \mathrm{~min})$.

GLP-1 and glucose infusions At time -30 min, an i.v. GLP1 (1.0 pmol kg ${ }^{-1} \mathrm{~min}^{-1}$; GLP-1 day) or saline (saline day) infusion was started using an automatic pump (Volumed $\mu \mathrm{VP}$ 5000; B. Braun Melsungen, Mannheim, Germany). A stepwise i.v. infusion of glucose $(20 \%$ dextrose) was started at time 0 min at rates of 2, 4, 6, 8 and $12 \mathrm{mg} \mathrm{kg}^{-1} \mathrm{~min}^{-1}$, with each infusion rate maintained for a period of $30 \mathrm{~min}$. Blood samples were drawn at time 10, 20 and $30 \mathrm{~min}$ of each 30 min period for measurements of plasma insulin, C-peptide and glucose. Every $30 \mathrm{~min}$ throughout the study and at time $-60,-30,-20,-10$ and $0 \mathrm{~min}$, blood samples were drawn for measurement of GLP-1 and glucagon.

\section{GLP-1}

Synthetic GLP-1 (7-36) amide was purchased from PolyPeptide Laboratories (Wolfenbuttel, Germany), and the same lot number was used in all studies. The peptide was dissolved in sterilised water containing $2 \%$ human serum albumin (Human Albumin, guaranteed to be free of hepatitis B surface antigen, hepatitis $C$ virus antibodies and human immunodeficiency virus antibodies; Statens Serum Institute, Copenhagen, Denmark), and subjected to sterile filtration. The GLP-1 was dispensed into glass ampoules and stored frozen $\left(-20^{\circ} \mathrm{C}\right)$ under sterile conditions until the day of the experiment. The peptide was demonstrated to be $>97 \%$ pure and identical to the natural human peptide by HPLC mass and sequence analysis.

\section{Biochemical analysis}

Blood samples for plasma glucose analysis were measured immediately in duplicate by the glucose oxidase method on a Beckman glucose analyser (Ramcon, Fullerton, CA, USA). Plasma insulin and C-peptide concentrations were measured by Auto-Delphia automatic fluoroimmunoassay (Wallac, Turku, Finland). Glucagon and total GLP-1 concentrations were measured after extraction of plasma with $70 \%$ ethanol (vol./vol., final concentration). The glucagon radioimmunoassay was directed against the $\mathrm{C}$-terminus of the glucagon molecule (antibody code no. 4305) and therefore mainly measures glucagon of pancreatic origin [21]. Total GLP-1 concentrations were determined using antiserum code no. 89390, which is specific for the amidated C-terminus of GLP-1, and which reacts equally with intact GLP-1 and with GLP-1 (9-36) amide, the primary metabolite [22]. Intact GLP-1 was measured using an ELISA, as previously described [23]. The assay is a two site sandwich assay employing two monoclonal antibodies: GLP-1F5 as the capture antibody (C-terminally directed) and Mab26.1 as detection antibody (N-terminally directed) [24].

\section{Assessment of insulin secretion rates}

Prehepatic insulin secretion rates (ISRs) for each individual were derived by deconvolution of peripheral C-peptide concentrations using a two compartment model of C-peptide kinetics $[25,26]$ and population-based C-peptide kinetic parameters [26]. The population-based parameters are derived from analysis of a large number of individual kinetic parameters, allowing calculation of values adjusted for 
clinical status (age, sex, degree of obesity and degree of glucose tolerance) [26]. ISR is expressed as pmol kg-1 $\mathrm{min}^{-1}$.

Relationship between glucose concentrations and insulin secretion

The calculated ISR values were plotted against the ambient plasma glucose to establish the dose-response relationship (responsiveness to glucose) for each individual on each experimental day. The slopes of these linear relationships were calculated by cross-correlation analysis, as previously described [9], and expressed as pmol $\mathrm{min}^{-1} \mathrm{~kg}^{-1}(\mathrm{mmol} / \mathrm{l})^{-1}$. The linearity of the relationship between glucose concentration and simultaneous ISR was assessed graphically in all $(n=54)$ cases and by calculation of the Pearson product moment correlation coefficient. There was no tendency to systematic deviations from linearity, and the correlation coefficients were high (median value 0.95 , interquartile range $0.88-0.97$ ). The minimum value was 0.71 . On this background the slopes of the linear relationships are considered to represent the beta cell responsiveness to the rise in glucose concentration under the different experimental conditions.

Statistical analysis and calculations

All results are presented as means \pm SEM unless otherwise stated. AUCs were calculated using the trapezoidal rule, and are presented as total AUC if nothing else is indicated. Standard statistical methods were employed for analysis and presentation of the data. Comparisons between the control participants and the patients were made by Mann-Whitney $U$ test. Comparisons before and after insulin treatment were made using the Wilcoxon signed rank sum test. A post hoc power analysis revealed that for near normalisation of glucose to have a significant effect $(80 \%$ power at significance level of $p=0.05$ ) on beta cell responsiveness to glucose alone after insulin treatment in the nine patients with type 2 diabetes without GLP-1, a responsiveness of $0.16 \mathrm{pmol} \mathrm{kg} \mathrm{min}^{-1}(\mathrm{mmol} / \mathrm{l})^{-1}$ is needed, which corresponds to a $50 \%$ increase in the mean value before normalisation of glucose $\left(0.33 \mathrm{pmol} \mathrm{kg}^{-1} \mathrm{~min}^{-1}[\mathrm{mmol} / 1]^{-1}\right.$; Table 3). Differences resulting in $p$ values of $<0.05$ were considered statistically significant.

\section{Results}

Insulin treatment

The patients were in poor glycaemic control before the start of insulin treatment, with an $\mathrm{HbA}_{1 \mathrm{c}}$ level of $8.0 \pm 0.4 \%$ (mean \pm SD), a fructosamine concentration of $317 \pm 20 \mu \mathrm{mol} / 1$ (mean \pm SD) and a mean blood glucose level of $11.7 \pm$ $1.2 \mathrm{mmol} / 1$, evaluated from seven point blood glucose profiles obtained daily for 3 days. During initiation of insulin treatment, a rapid improvement in glycaemic control was observed, resulting in a mean blood glucose level over the 4 weeks of insulin treatment of $6.4 \pm 0.3 \mathrm{mmol} / \mathrm{l}$ (Fig. 1). At the end of the treatment period, $\mathrm{HbA}_{1 \mathrm{c}}(6.7 \pm 0.3 \%$, mean \pm SD) and fructosamine $(243.9 \pm 11 \mu \mathrm{mol} / 1$, mean \pm SD) were significantly reduced compared with baseline. The mean total daily dose of insulin was $92 \pm 9$ IU (mean \pm SD).

\section{Mean plasma GLP-1}

The GLP-1 infusions resulted in significant increases in total and intact GLP-1 concentrations (Fig. 2a and b, respectively). Mean plasma GLP-1 concentrations from 0$150 \mathrm{~min}$ were $188.0 \pm 31.8$ and $219.2 \pm 28.8 \mathrm{pmol} / 1$ in the patients before and after insulin treatment, respectively, and $201.1 \pm 27.0 \mathrm{pmol} / 1$ in the healthy participants $(p=\mathrm{NS})$. The corresponding concentrations for intact GLP-1 were 25.5 \pm $1.8,23.5 \pm 1.6$ and $22.5 \pm 2.1 \mathrm{pmol} / 1$, respectively $(p=\mathrm{NS})$. During saline infusions, the endogenous concentrations of total GLP-1 were $9.4 \pm 1.9,9.6 \pm 2.0$ and $10.0 \pm 3.7 \mathrm{pmol} / 1$ before insulin treatment, after insulin treatment and in the healthy participants, respectively $(p=\mathrm{NS})$. No side effects were registered during the GLP-1 infusions in the patients with type 2 diabetes, while one of the healthy participants reported mild nausea.

\section{Response to graded glucose infusion}

At baseline, fasting plasma glucose was similar on the GLP1 and saline days $(8.6 \pm 0.4$ and $8.4 \pm 0.4 \mathrm{mmol} / \mathrm{l}$, respectively; $p=\mathrm{NS}$; Fig. 3, Table 2). Insulin treatment for 4 weeks resulted in significant reductions in fasting plasma glucose, with values of $7.0 \pm 0.5$ and $7.3 \pm 0.4 \mathrm{mmol} / \mathrm{l}$ obtained on the GLP-1 and saline days, respectively $(p=\mathrm{NS})$. After initial i.v. administration of insulin $\left(0.1 \mathrm{IU} \mathrm{kg}^{-1} \mathrm{~h}^{-1}\right)$, normoglycaemia

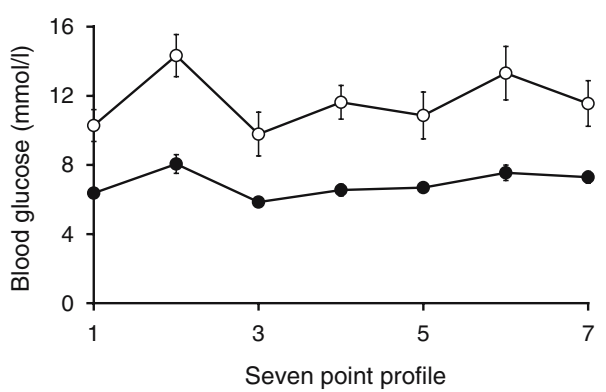

Fig. 1 Mean blood glucose before (white circles) and during 4 weeks of insulin treatment (black circles). The patients measured blood glucose seven times daily three times weekly. Data are means \pm SEM 
a

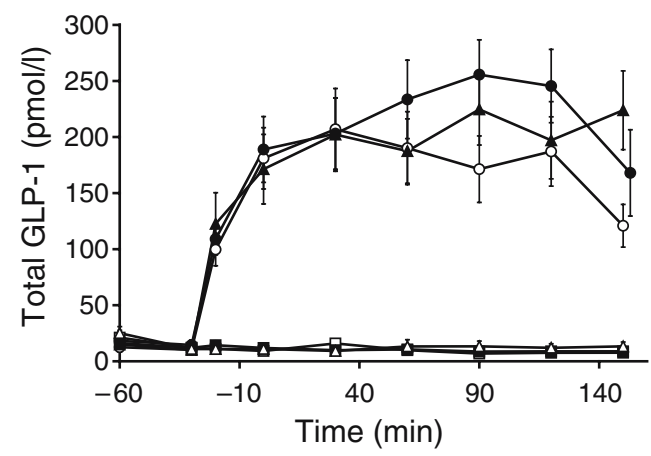

b

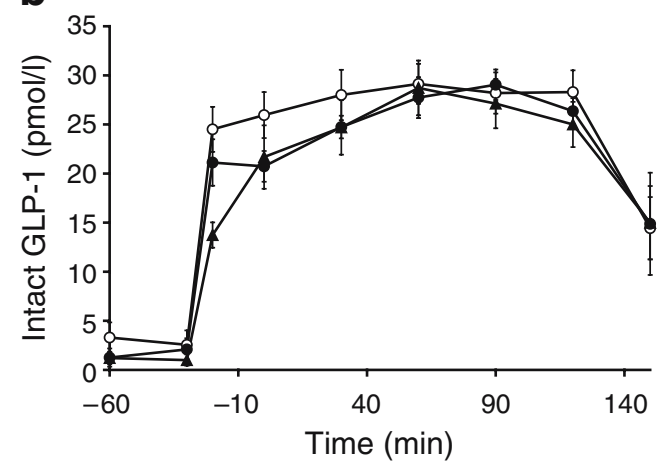

Fig. 2 Total (a) and intact (b) GLP-1 concentrations during GLP-1 infusions before (white circles) and after (black circles) insulin treatment and during saline infusions before (white squares) and after (black squares) insulin treatment in patients 2 diabetes; and during GLP-1 (black triangles) and saline (white triangles) infusions in healthy participants

was achieved in the patients (mean $5.0 \pm 0.3 \mathrm{mmol} / \mathrm{l}$, range 4.4-6.0). The mean fasting plasma glucose concentration in the healthy participants before the start of the experiment was $5.8 \pm 0.1 \mathrm{mmol} / 1$ (range 5.0-6.1).

Glucose profiles did not differ during infusion of glucose and saline between baseline and after 4 weeks of insulin treatment in the type 2 diabetic patients, with mean plasma glucose concentrations $(0-150 \mathrm{~min})$ of $13.1 \pm 1.4$ and $12.4 \pm$ $1.3 \mathrm{mmol} / 1(p=\mathrm{NS})$ and mean peak values of $22.9 \pm 1.0$ and $21.5 \pm 1.2 \mathrm{mmol} / \mathrm{l}(p=\mathrm{NS})$, respectively, observed (Fig. 3a, Table 2). Both mean plasma glucose and mean peak plasma glucose concentrations were significantly lower on the GLP-1 day than during the saline day $(p<0.05)$. On the GLP-1 days, mean plasma glucose concentrations were $10.6 \pm 1.0$ and $10.0 \pm 1.0 \mathrm{mmol} / \mathrm{l}(p=\mathrm{NS})$ before and after insulin treatment, respectively and mean peak plasma glucose concentrations were $17 \pm 1.5$ and $16.5 \pm 1.2 \mathrm{mmol} / \mathrm{l}$ $(p=\mathrm{NS})$, respectively, resulting in a higher $\mathrm{AUC}_{\text {plasma glucose }}$ on the saline days than on the GLP-1 days (Fig. 3a, Table 2). The mean plasma glucose value in healthy participants on the saline day was $10.4 \pm 0.9 \mathrm{mmol} / \mathrm{l}$ and the mean peak concentration of $16.0 \pm 0.7 \mathrm{mmol} / \mathrm{l}$, with corresponding values of $6.8 \pm 0.3$ and $8.3 \pm 0.2 \mathrm{mmol} / \mathrm{l}$, respectively, on the GLP-1 day
(Fig. 3b, Table 2). The plasma glucose AUC in the healthy participants on the saline day was not statistically different from that in the patients on the GLP-1 days (Table 2).

Insulin and C-peptide

In the patients, $\mathrm{AUC}_{\text {insulin }}$ on the saline days was higher after than before insulin treatment ( $p=0.04$; Table 2, Fig. 3c), whereas there was no difference in $\mathrm{AUC}_{\mathrm{C}-\text { peptide }}(p=\mathrm{NS}$; Fig. 3e, Table 2). In contrast, on the GLP-1 days, both $\mathrm{AUC}_{\text {insulin }}$ and $\mathrm{AUC}_{\mathrm{C} \text {-peptide }}$ were higher after than before insulin treatment $(p=0.02)$. Furthermore, $\mathrm{AUC}_{\text {insulin }}$ and

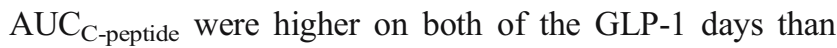
on the saline days (Fig. 3c,e; Table 2). In the healthy participants, $\mathrm{AUC}_{\text {insulin }}$ and $\mathrm{AUC}_{\mathrm{C} \text {-peptide }}$ were higher during the GLP-1 day than during the saline day $(p<0.001$; Fig. 3 d,f; Table 2). $\mathrm{AUC}_{\mathrm{C} \text {-peptide }}$ during the saline day in healthy participants was similar to that observed during the GLP-1 days in patients with type 2 diabetes ( $p=\mathrm{NS}$; Table 2 ).

Insulin secretion rate (ISR) The ISRs in the patients and healthy participants are presented in Fig. $3 \mathrm{~g}$ and $\mathrm{h}$, respectively. $\mathrm{AUC}_{\mathrm{ISR}}$ was higher in patients with type 2 diabetes on the GLP-1 days than on the saline days, both before and after insulin treatment $(p<0.05$, Table 2$)$. Insulin treatment had no significant effect on $\mathrm{AUC}_{\mathrm{ISR}}$ on the saline days, whereas total $\mathrm{AUC}_{\mathrm{ISR}}$ was significantly greater after insulin treatment on the GLP-1 day $(p<0.05)$. In healthy participants, total $\mathrm{AUC}_{\mathrm{ISR}}$ was, as expected, higher during the GLP-1 day than during the saline day $(p=0.004$; Fig. 3h, Table 2). There was no difference between $\mathrm{AUC}_{\mathrm{ISR}}$ in healthy participants on the saline day and the patients on the GLP-1 days $(p=\mathrm{NS})$.

Effect of GLP-1 on the relationship between glucose and ISR The responsiveness of the beta cells to changes in plasma glucose, evaluated from the slope of the line expressing the relationship between ISR and plasma glucose concentration, was impaired in the patients (Table 3). Insulin treatment had no significant effect on beta cell responsiveness to changes in glucose concentration on the saline days $(p=0.4)$, whereas the beta cell responsiveness on the GLP-1 days was improved after insulin treatment $(p<0.01$; Table 3$)$. In both patients and healthy participants, the glucose response to GLP-1 was greater than that to saline, such that in the patients, beta cell sensitivity to glucose on the GLP-1 days was higher than that in healthy participants on the saline days.

Glucagon The dynamic profiles of plasma glucagon are presented in Fig. $3 \mathrm{i}$ and $\mathrm{j}$. The incremental $\mathrm{AUC}_{\text {glucagon }}$ below baseline did not differ during GLP-1 infusion compared with saline infusion in both patients with type 2 diabetes and in healthy participants (Table 2). In the 
Fig. 3 Plasma glucose (a, b), insulin (c, d), C-peptide (e, f), insulin secretion rate (ISR) $(\mathbf{g}, \mathbf{h})$ and glucagon $(\mathbf{i}, \mathbf{j})$ in patients with type 2 diabetes (a, c, e, g, i), and healthy participants $(\mathbf{b}, \mathbf{d}, \mathbf{f}, \mathbf{h}, \mathbf{j})$, respectively, during GLP-1 infusions before (white circles) and after (black circles), and during saline infusions before (white squares) and after (black squares) 4 weeks of insulin treatment in patients 2 diabetes, and during GLP-1 (black triangles) and saline (white triangles) infusions in healthy participants. Differences between experiments are given in Table 2 a

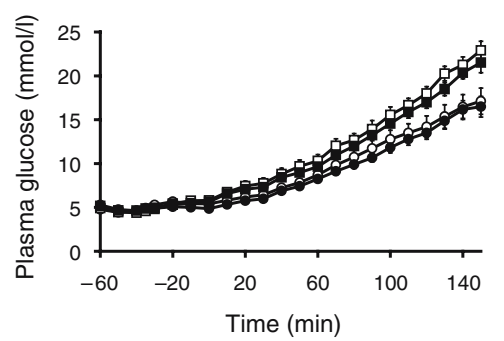

C

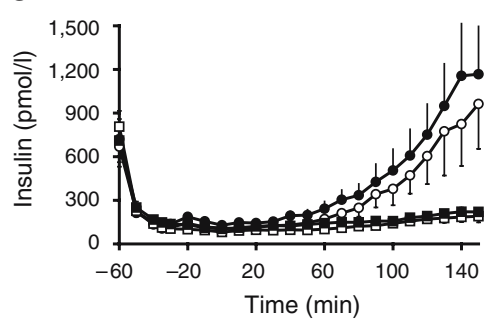

e

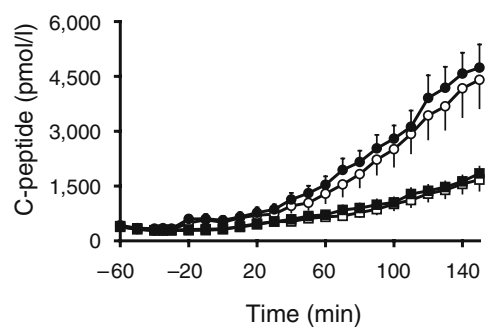

g
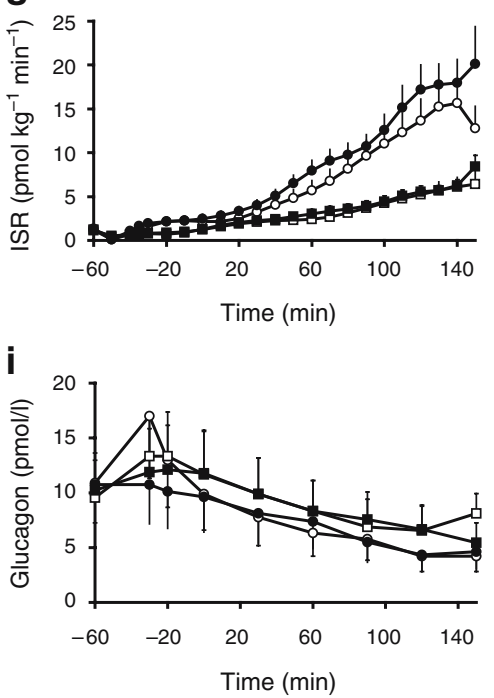

b

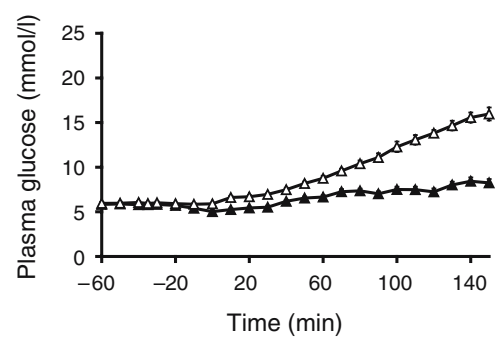

d

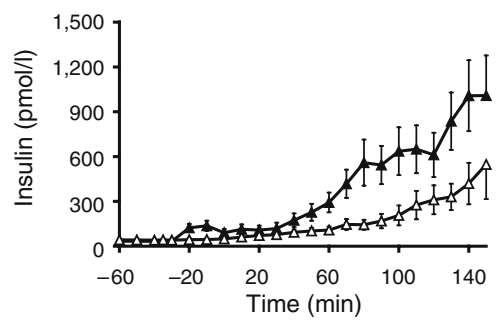

f

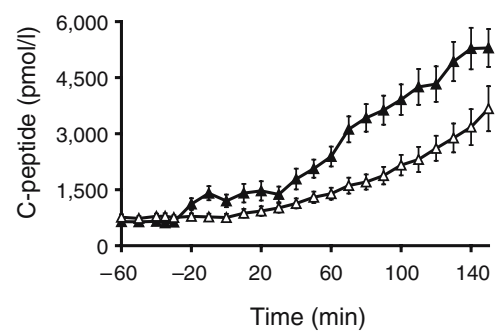

h
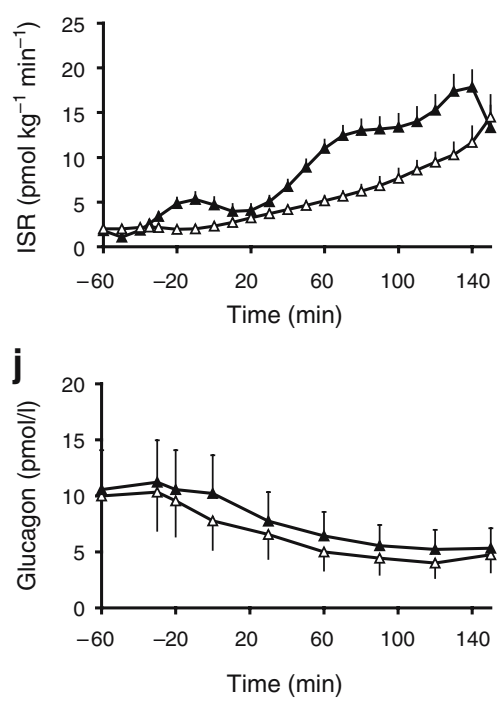

patients, insulin treatment did not increase suppression of glucagon on either day (Table 2).

\section{Discussion}

In the present experiments, 4 weeks of insulin treatment with near normalisation of blood glucose in patients with type 2 diabetes did not significantly change beta cell responsiveness to glucose per se. However, maintenance of near-normal glycaemia resulted in an improvement in beta cell sensitivity to GLP-1, as indicated by the greater glucose-induced insulin release in the presence of GLP-1 at week 4 compared with baseline. Furthermore, beta cell responsiveness to glucose during GLP-1 infusion in the patients was greater than that observed during saline infusion in the healthy control group. However, near 
Table 2 Total area under the plasma glucose, insulin, C-peptide and ISR curves and area under baseline (suppression) glucagon curve, during GLP-1 and saline infusions, before and after insulin treatment

\begin{tabular}{llllll}
\hline & $\begin{array}{l}\text { Plasma glucose AUC } \\
\left(\mathrm{mmol} \mathrm{l} \mathrm{min}^{-1}\right) \\
(-30-150 \mathrm{~min})\end{array}$ & $\begin{array}{l}\text { Insulin AUC } \\
\left(\mathrm{nmol} \mathrm{l} \mathrm{min}^{-1}\right) \\
(-30-150 \mathrm{~min})\end{array}$ & $\begin{array}{l}\text { C-peptide AUC } \\
\left(\mathrm{nmol} \mathrm{l} \mathrm{min}^{-1}\right) \\
(-30-150 \mathrm{~min})\end{array}$ & $\begin{array}{l}\text { ISR } \\
\left(\mathrm{pmol} \mathrm{kg}^{-1}\right. \\
\left.180 \mathrm{~min}^{-1}\right)\end{array}$ & $\begin{array}{l}\text { Glucagon IAUC } \\
\left(\mathrm{pmol} \mathrm{l}^{-1} \mathrm{~min}^{-1}\right) \\
\left(0-150 \mathrm{~min}^{-1}\right.\end{array}$ \\
\hline $\begin{array}{l}\text { Patients with T2DM + saline } \\
\text { Before }\end{array}$ & $2,120.1 \pm 116.3$ & $21.0 \pm 2.47^{*}$ & $124.26 \pm 19.36$ & $569.2 \pm 93.6$ & $-777 \pm 234$ \\
After & $2,000.8 \pm 72.2$ & $25.72 \pm 2.79$ & $134.19 \pm 16.38$ & $618.1 \pm 80.4$ & $-808 \pm 198$ \\
Patients with T2DM + GLP-1 & & & & & \\
Before & $1,744.9 \pm 120.1$ & $50.59 \pm 14.14^{*}$ & $268.22 \pm 47.46^{*}$ & $1,309.9 \pm 225.1^{*}$ & $-760 \pm 118$ \\
After & $1,640.9 \pm 69.7$ & $74.48 \pm 18.04$ & $329.13 \pm 46.93$ & $1,607.9 \pm 223.0$ & $-638 \pm 186$ \\
Healthy controls + saline & $1,737.9 \pm 48.0^{\dagger}$ & $28.66 \pm 8.12^{\dagger}$ & $267.17 \pm 33.12^{\dagger}$ & $1,109.2 \pm 125.9^{\dagger}$ & $-752 \pm 98^{\dagger}$ \\
Healthy controls + GLP-1 & $1,190.9 \pm 35.2$ & $70.46 \pm 5.96$ & $453.94 \pm 50.3$ & $1,849.4 \pm 175.2$ & $-558 \pm 89$ \\
\hline
\end{tabular}

$n=9$ in each group

IAUC, incremental AUC; T2DM, type 2 diabetes

${ }^{*} p<0.05$ before and after insulin treatment in patients with type 2 diabetes

${ }^{\dagger} p<0.05$ between saline and GLP-1 infusions in the healthy subjects

normalisation of blood glucose had no effect on suppression of glucagon secretion induced by glucose alone or in combination with GLP-1.

The present investigations were inspired by our previous dose-response study of the effect of GLP-1 on beta cell responsiveness in patients with 2 diabetes and healthy participants [9], which showed that GLP-1 potentiates glucose-induced insulin secretion in a dose-dependent manner, and that beta cell responsiveness to glucose can be normalised by the infusion of a relatively low dose of GLP-1. This is in accordance with results from other studies showing that GLP-1 or GLP-1 analogues can improve beta cell responses to glucose in patients with type 2 diabetes [7, 9, 27]. However, the results of our previous study also indicated that the potency of GLP-1 with respect to enhancing beta cell responsiveness to glucose was severely diminished in patients with type 2

Table 3 Beta cell responsiveness during GLP-1 and saline infusions, before and after insulin treatment

\begin{tabular}{ll}
\hline & $\begin{array}{l}\text { Beta cell responsiveness } \\
\left(\mathrm{pmol} \mathrm{kg} \mathrm{min}^{-1}[\mathrm{mmol} /]^{-1}\right)\end{array}$ \\
\hline $\begin{array}{l}\text { Patients with T2DM + saline } \\
\text { Before }\end{array}$ & $0.33 \pm 0.07^{\mathrm{a}}$ \\
After & $0.39 \pm 0.04$ \\
Patients with T2DM + GLP-1 & \\
Before & $1.27 \pm 0.20^{\mathrm{b}}$ \\
After & $1.73 \pm 0.31$ \\
Healthy controls + saline & $1.01 \pm 0.14^{\mathrm{c}}$ \\
Healthy controls + GLP-1 & $4.79 \pm 0.53$ \\
\hline
\end{tabular}

$n=9$ in each group

${ }^{\mathrm{a}} p=\mathrm{NS}$ vs patients with $\mathrm{T} 2 \mathrm{DM}+$ saline after insulin injection

${ }^{\mathrm{b}} p=0.01$ vs patients with T2DM + GLP-1 after insulin injection

${ }^{c} p=0.004$ vs healthy controls + GLP-1

T2DM, type 2 diabetes diabetes [9], a finding confirmed in the present study. There is considerable evidence that prolonged exposure of the beta cell to high glucose levels in patients with type 2 diabetes induces functional defects in insulin secretion, both in response to glucose and non-glucose secretagogues $[2,7-9,11-17]$. Therefore, we hypothesised that aggressive insulin treatment resulting in near normalisation of diurnal blood glucose may improve beta cell responsiveness to glucose and the potentiating effect of GLP-1 on glucoseinduced insulin secretion. However, in the current study, 4 weeks of insulin treatment resulted in only minor, nonsignificant improvements in beta cell responsiveness to glucose. In contrast, the potentiating effect of GLP-1 on glucose-induced insulin secretion was significantly improved by about $30 \%$ after 4 weeks of insulin treatment. Nevertheless, responsiveness to glucose was still reduced to one-third of that observed in the healthy controls on the GLP-1 day, despite plasma levels of GLP-1 that were two to three times greater than those observed postprandially in healthy controls. The increased GLP-1 levels achieved during infusion were within the therapeutic range obtained during treatment with GLP-1 analogues [10].

A number of previous studies have addressed the effect of insulin treatment and strict glycaemic control on beta cell function [12-17]. Vague and Moulin found that $20 \mathrm{~h}$ of normoglycaemia may be sufficient to partially restore the first-phase insulin response to i.v. glucose in patients with type 2 diabetes [17]. Similarly, in patients with mild type 2 diabetes, Turner and co-workers demonstrated that 3 days of normoglycaemia enhanced the first-phase insulin response to i.v. glucose [16]. Other studies demonstrated that the insulin responses to a mixed meal, oral glucose and i.v. glucagon in patients with 2 diabetes all increased with improvement of glucose control, regardless of treatment (diet, sulfonylurea or insulin), suggesting that amelioration 
of glucose toxicity and removal of beta cell stress improves beta cell function [12-14]. We, therefore hypothesised that 4 weeks of near normalisation of blood glucose should be sufficient to demonstrate a beneficial effect on beta cell function, since previous studies in patients and animals with type 2 diabetes have indicated that a few days of near normalisation of blood glucose improves beta cell function $[16,17,28]$. However, in the present study, there was no significant effect of intensive insulin treatment on beta cell sensitivity to glucose. It appears unlikely that we may have overlooked an existing effect, since we used a sensitive method for evaluating beta cell responsiveness [29] that allowed us to obtain an accurate and precise index of beta cell function, independent of hepatic insulin extraction, which was based on a large number of data points from each individual. It is possible that if we had included patients with a higher baseline $\mathrm{HbA}_{1 \mathrm{c}}$, we may have been more likely to identify a change in the beta cell responsiveness to glucose alone, while a more longstanding reduction of hyperglycaemia may have resulted in a greater improvement in beta cell sensitivity.

In type 2 diabetes, excess glucagon secretion plays an important role in promoting both basal and postprandial hyperglycaemia [18]. In the present study, insulin treatment had no effect on the glucagon response to graded glucose infusion. Glucagon suppression during saline infusion and GLP-1 infusion was similar, both in the participants with type 2 diabetes or in the control participants. This is in contrast to other studies which have shown an inhibiting effect of GLP-1 on glucagon release patients with 2 diabetes and in patients with type 1 diabetes $[7,8,19,20]$.

It should be acknowledged that our study is subject to certain limitations. Diurnal blood glucose levels were not completely normalised and, therefore, 'glucotoxicity' was not totally eliminated. However, $\mathrm{HbA}_{1 \mathrm{c}}$ averaged $6.6 \%$ after 4 weeks of insulin treatment, and the mean blood glucose was $6.4 \mathrm{mmol} / \mathrm{l}$, even when including postprandial levels in the calculation, and so it will be very difficult to further improve glycaemic control without unacceptably increasing the risk of severe hypoglycaemia, even using a continuous subcutaneous insulin infusion [30, 31].

In conclusion, 4 weeks of near normalisation of blood glucose had no effect on beta cell sensitivity to glucose, and did not increase glucagon suppression during hyperglycaemia either in the absence or presence of GLP-1. However, near normalisation of glycaemia significantly improved beta cell sensitivity to GLP-1, suggesting that the impaired action of GLP-1 in patients with type 2 diabetes may be secondary to the lack of metabolic control. This raises the possibility that the effect of GLP-1 treatment on hyperglycaemia may gradually improve with amelioration of hyperglycaemia during treatment with antihyperglycaemic agents, i.e. dipeptidyl peptidase 4 inhibitors.
Acknowledgements We are grateful to our volunteers whose participation made this work possible, and to S. Reimer and $\mathrm{L}$. Albeck for technical assistance. Special thanks to J. M. Højberg, for helping with the insertion of difficult i.v. catheters. This study was supported by the Hvidovre Hospitals research foundation, the Danish Diabetes Association, the Novo Nordisk Foundation, the Medical Science Research Foundation for Copenhagen, Faeroe Islands and Greenland, and the Danish Research Agency (Ministry of Science, Technology and Innovation).

Duality of interest S Madsbad has served as a consultant or adviser to: Novartis Pharmaceuticals; Novo Nordisk; Merck, Sharp and Dome; Pfizer; Abbott Laboratories; Sanofi-Aventis; Astra-Zeneca; and Johnson \& Johnson. The remaining authors declare that there is no duality of interest associated with this manuscript.

\section{References}

1. Butler AE, Janson J, Bonner-Weir S, Ritzel R, Rizza RA, Butler PC (2003) Beta-cell deficit and increased beta-cell apoptosis in humans with type 2 diabetes. Diabetes 52:102-110

2. Porte D Jr (1991) Banting lecture 1990. Beta-cells in type II diabetes mellitus. Diabetes 40:166-180

3. Nauck MA, Bartels E, Orskov C, Ebert R, Creutzfeldt W (1993) Additive insulinotropic effects of exogenous synthetic human gastric inhibitory polypeptide and glucagon-like peptide-1-(7-36) amide infused at near-physiological insulinotropic hormone and glucose concentrations. J Clin Endocrinol Metab 76:912-917

4. Nauck MA, Homberger E, Siegel EG et al (1986) Incretin effects of increasing glucose loads in man calculated from venous insulin and $\mathrm{C}$-peptide responses. J Clin Endocrinol Metab 63:492-498

5. Nauck M, Stockmann F, Ebert R, Creutzfeldt W (1986) Reduced incretin effect in type 2 (non-insulin-dependent) diabetes. Diabetologia 29:46-52

6. Tronier, B, Dejgaard A, Madsbad S (1985) Absence of incretin effect in obese type 2 and diminished effect in lean type 2 and obese subjects. Diabetes Res Clin Pract (Suppl 1):S568

7. Vilsbøll T, Krarup T, Madsbad S, Holst JJ (2002) Defective amplification of the late phase insulin response to glucose by GIP in obese type II diabetic patients. Diabetologia 45:1111-1119

8. Vilsbøll T, Knop FK, Krarup T et al (2003) The pathophysiology of diabetes involves a defective amplification of the late-phase insulin response to glucose by glucose-dependent insulinotropic polypeptide-regardless of etiology and phenotype. J Clin Endocrinol Metab 88:4897-4903

9. Kjems LL, Holst JJ, Vølund A, Madsbad S (2003) The influence of GLP-1 on glucose-stimulated insulin secretion: effects on betacell sensitivity in type 2 and nondiabetic subjects. Diabetes 52: 380-386

10. Zander M, Madsbad S, Madsen JL, Holst JJ (2002) Effect of 6-week course of glucagon-like peptide 1 on glycaemic control, insulin sensitivity, and beta-cell function in type 2 diabetes: a parallel-group study. Lancet 359:824-830

11. Poitout V, Robertson RP (2002) Minireview: secondary beta-cell failure in type 2 diabetes - a convergence of glucotoxicity and lipotoxicity. Endocrinology 143:339-342

12. Garvey WT, Olefsky JM, Griffin J, Hamman RF, Kolterman OG (1985) The effect of insulin treatment on insulin secretion and insulin action in type II diabetes mellitus. Diabetes 34:222-234

13. Hidaka H, Nagulesparan M, Klimes I et al (1982) Improvement of insulin secretion but not insulin resistance after short term control 
of plasma glucose in obese type II diabetics. J Clin Endocrinol Metab 54:217-222

14. Kosaka K, Kuzuya T, Akanuma Y, Hagura R (1980) Increase in insulin response after treatment of overt maturity-onset diabetes is independent of the mode of treatment. Diabetologia 18:23-28

15. Schmeltz R, Wendorff HJ, Field JB (1978) Effect of control of blood glucose on plasma insulin responses to various stimuli in secondary failures to oral hypoglycemic agents and in newly diagnosed, maturity onset, ketosis-resistant diabetics. J Clin Endocrinol Metab 46:519-527

16. Turner RC, McCarthy ST, Holman RR, Harris E (1976) Beta-cell function improved by supplementing basal insulin secretion in mild diabetes. BMJ 1:1252-1254

17. Vague P, Moulin JP (1982) The defective glucose sensitivity of the B cell in non insulin dependent diabetes. Improvement after twenty hours of normoglycaemia. Metabolism 31:139-142

18. Shah P, Vella A, Basu A, Basu R, Schwenk WF, Rizza RA (2000) Lack of suppression of glucagon contributes to postprandial hyperglycemia in subjects with type 2 diabetes mellitus. J Clin Endocrinol Metab 85:4053-4059

19. Gutniak M, Orskov C, Holst JJ, Ahren B, Efendic S (1992) Antidiabetogenic effect of glucagon-like peptide-1 (7-36)amide in normal subjects and patients with diabetes mellitus. N Engl J Med 326:1316-1322

20. Nauck MA, Kleine N, Orskov C, Holst JJ, Willms B, Creutzfeldt W (1993) Normalization of fasting hyperglycaemia by exogenous glucagon-like peptide 1 (7-36 amide) in type 2 (non-insulin-dependent) diabetic patients. Diabetologia 36:741-744

21. Deacon CF, Nauck MA, Meier J, Hucking K, Holst JJ (2000) Degradation of endogenous and exogenous gastric inhibitory polypeptide in healthy and in type 2 diabetic subjects as revealed using a new assay for the intact peptide. J Clin Endocrinol Metab $85: 3575-3581$
22. Holst JJ (1982) Evidence that enteroglucagon (II) is identical with the C-terminal sequence (residues 33-69) of glicentin. Biochem J 207:381-388

23. Vilsbøll T, Krarup T, Sonne J et al (2003) Incretin secretion in relation to meal size and body weight in healthy subjects and people with type 1 and type 2 diabetes mellitus. J Clin Endocrinol Metab 88:2706-2713

24. Wilken M, Larsen FS, Buckley D, Holst JJ (1999) New highly specific immunoassays for glucagon-like peptide 1 (GLP-1). Diabetologia 42:A196

25. Kjems LL, Christiansen E, Vølund A, Bergman RN, Madsbad S (2000) Validation of methods for measurement of insulin secretion in humans in vivo. Diabetes 49:580-588

26. Van Cauter E, Mestrez F, Sturis J, Polonsky KS (1992) Estimation of insulin secretion rates from C-peptide levels. Comparison of individual and standard kinetic parameters for C-peptide clearance. Diabetes 41:368-377

27. Chang AM, Jakobsen G, Sturis J et al (2003) The GLP-1 derivative NN2211 restores beta-cell sensitivity to glucose in type 2 diabetic patients after a single dose. Diabetes 52:1786-1791

28. Kergoat M, Bailbe D, Portha B (1987) Insulin treatment improves glucose-induced insulin release in rats with NIDDM induced by streptozocin. Diabetes 36:971-977

29. Byrne MM, Sturis J, Clement K et al (1994) Insulin secretory abnormalities in subjects with hyperglycemia due to glucokinase mutations. J Clin Invest 93:1120-1130

30. Herman WH, Ilag LL, Johnson SL et al (2005) A clinical trial of continuous subcutaneous insulin infusion versus multiple daily injections in older adults with type 2 diabetes. Diabetes Care 28:1568-1573

31. Raskin P, Bode BW, Marks JB et al (2003) Continuous subcutaneous insulin infusion and multiple daily injection therapy are equally effective in type 2 diabetes: a randomized, parallelgroup, 24-week study. Diabetes Care 26:2598-2603 